\title{
Modelling the effects of forest management intensification on base cation concentrations in soil water and on tree growth in spruce forests in Sweden
}

\author{
Giuliana Zanchi $^{1}\left[\right.$ Klas Lucander $^{1} \cdot$ Veronika Kronnäs $^{1} \cdot$ Martin Erlandsson Lampa $^{2} \cdot$ Cecilia Akselsson $^{1}$
}

Received: 18 January 2021 / Revised: 26 July 2021 / Accepted: 6 August 2021 / Published online: 19 August 2021

(c) The Author(s) 2021

\begin{abstract}
The study investigated the effects of forest residue extraction on tree growth and base cations concentrations in soil water under different climatic conditions in Sweden. For this purpose, the dynamic model ForSAFE was used to compare the effects of whole-tree harvesting and stem harvesting on tree biomass and the soil solution over time at 6 different forest sites. The study confirmed the results from experimental sites showing a temporary reduction of base cation concentration in the soil solution for a period of 20-30 years after whole-tree harvesting. The model showed that this was mainly caused by the reduced inputs of organic material after residue extraction and thereby reduced nutrient mineralisation in the soil. The model results also showed that whole-tree harvesting can affect tree growth at nitrogen-poor forest sites, such as the ones in northern Sweden, due to the decrease of nitrogen availability after residue removal. Possible ways of reducing this impact could be to compensate the losses with fertilisation or extract residue without foliage in areas of Sweden with low nitrogen deposition. The study highlighted the need to better understand the medium- and long-term effects of whole-tree harvesting on tree growth, since the results suggested that reduced tree growth after whole-tree harvesting could be only temporary. However, these results do not account for prolonged extraction of forest residues that could progressively deplete nutrient pools and lead to permanent effects on tree growth.
\end{abstract}

Keywords Whole-tree harvesting $\cdot$ Base cations $\cdot$ ForSAFE $\cdot$ Tree growth

\section{Introduction}

Forest biomass is one of the key resources that will be used in the European Union to increase renewable energy production and comply with emission reduction targets set by climate change policies. One of the strategies implemented to increase biomass production from forests is to increase the extraction of harvest residues, such as tops and branches. It was assessed that forest residues and stumps could contribute to $12 \%$ of the primary forest biomass potential in Europe and Sweden would be one of the main supply countries

Communicated by Agustín Merino.

Giuliana Zanchi

giuliana.zanchi@nateko.lu.se

1 Department of Physical Geography and Ecosystem Science, Lund University, Sölvegatan 12, 22362 Lund, Sweden

2 Water Authority of the North Baltic Sea Water District, 72186 Västerås, Sweden together with Germany, France and Finland (Lindner et al. 2017). As a consequence, the harvesting of forest residues is expected to increase in Sweden to meet the increasing demand for biomass (SKA 2015). However, while the Swedish Energy Agency advocates for a progressive increase of bioenergy production from forest biomass to reduce GHG emissions, it also requires that increased biomass extraction from forests, such as residue extraction, does not compromise the achievement of other environmental goals (Swedish Energy Agency 2011).

One of the possible negative effects of extracting forest residues, through whole-tree harvesting, is the longterm loss of base cations that can lead to soil acidification (Clarke et al. 2021; Johnson et al. 2015; Kimmins 1976; Kreutzweiser et al. 2008). Taking this negative effect into account, de Jong et al. (2017) assessed that wholetree harvesting is sustainable only if wood ash recycling is applied but also that ash production is only enough to compensate for whole-tree harvesting of about $50 \%$ of the clear-felled area in Sweden. That is, there is a constrained 
availability of suitable-quality ash that create a mismatch between demand and supply of ash for recycling which is likely to persist in the future. As a consequence, it will be important to concentrate the ash recycling to the areas which are most sensitive to acidification (Swedish Energy Agency 2014).

The identification of acid-sensitive areas requires an understanding of how the effects of whole-tree harvesting vary in space and time. Long-term experiments have confirmed that residue extraction can temporarily reduce base cation pools (Brandtberg and Olsson 2012; Clarke et al. 2021; Premer et al. 2019; Zetterberg et al. 2013, 2016) and base cation concentrations in soil solution (Ring et al. 2017; Zetterberg et al. 2013), but due to their limited spatial and temporal distribution they cannot support general conclusions on which areas are and will be more susceptible to acidification (Ouimet et al. 2021; Premer et al. 2019). The integration of model simulation with experimental results is often suggested as a solution to better understand how the effects of forest residue extraction on base cation availability and acidification differ in time and space (Akselsson et al. 2021; Löfgren et al. 2017; Valipour et al. 2018). However, previous model assessments have shown stronger negative effects of residue extraction than expected based on the long-term experiments, both regarding base cation pools in soil and ANC in surface water (Aherne et al. 2012; Zetterberg et al. 2013, 2014). Moreover, they have not been able to reproduce the decreasing differences in acidity-related effects between stem- and whole-tree harvesting, leading to small or no differences in soil and soil solution after 30-40 years. It was hypothesized that the reason behind the deviation between model results and measurements was a lack of dynamics in these models in key processes regulating base cation cycling (e.g. weathering and vegetation uptake) (Erlandsson Lampa et al. 2020; Paré and Thiffault 2016).

Loss of nutrients through residues extraction can also have negative consequences on tree growth, but the effects vary significantly among different sites and over time (Achat et al. 2015; Ouimet et al. 2021; Thiffault et al. 2011), further contributing to the uncertainty around the management measures that should be implemented to reduce negative impacts of intensified wood extraction (Lim et al. 2020; Raulund-Rasmussen et al. 2008; Vanguelova et al. 2010).

This study aimed to investigate the effects of forest residue extraction on base cations concentrations in soil water and tree biomass in different climatic regions in Sweden. For this purpose, the dynamic model ForSAFE was used to simulate the effects of whole-tree harvesting as compared to stem harvesting at 6 forest sites distributed over Sweden. ForSAFE includes all the main processes regulating base cation cycling in forest ecosystems and can help closing knowledge gaps on the processes regulating base cation losses in different environmental conditions.

\section{Materials and methods}

\section{Description of sites}

The study includes the simulation of tree biomass and soil water chemistry under stem and whole-tree harvesting at six sites included in the long-term monitoring Swedish Throughfall Monitoring Programme (SWETHRO). SWETHRO is a unique monitoring network of about 60 Swedish forests sites distributed across the entire country (Pihl Karlsson et al. 2011). Data on deposition and soil water chemistry are collected at the sites. In addition, data on tree diameter distribution and soil chemistry are reported for most of the sites. The length of the data series is variable, stretching back up to 30 years for the initial sites that were established in 1985. The SWETHRO sites are often in forest areas included in the Level II of ICP forests, i.e. forest sites part of the International Co-operative Programme on Assessment and Monitoring of Air Pollution Effects on Forests operating under the UNECE Convention on Long-range Transboundary Air Pollution. Four of the sites included in this study are also part of the ICP network which provides additional data on tree diameter distribution at different points in time, soil chemistry and other parameters such as foliage chemistry and defoliation. The sites included in this study are all spruce dominated forests but distributed in six different climatic regions in Sweden as outlined in the CLEO project based on 18 regions used by SMHI in weather forecasting (SEPA 2016) (Fig. 1). Further information on the sites is reported in Table 1.

\section{The ForSAFE model}

ForSAFE is a dynamic ecosystem model developed to assess the effects of environmental changes on forest ecosystems. ForSAFE can simulate the effect of changes in climate, forest management and deposition. Input data to the model include time series of climate, deposition and management scenarios, as well as soil and vegetation data (Fig. 2). Based on climatic condition and tree species, the model simulates the potential vegetation growth at the site which is translated into a water and nutrient demand. The potential growth is constrained to actual biomass growth by water and nutrient availability in the soil and 


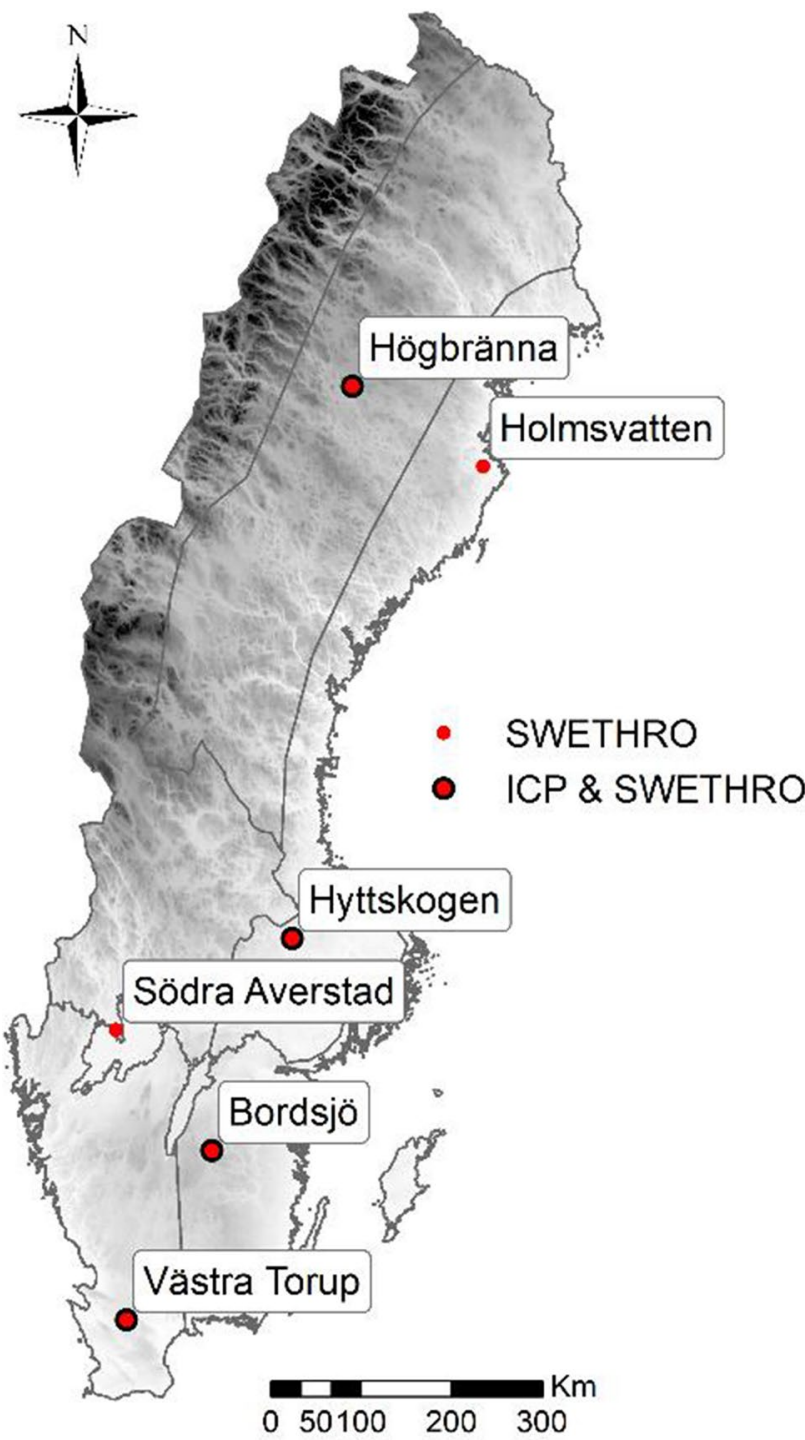

Fig. 1 Location of the SWETHRO sites (red dots) simulated in this study, distributed in 6 different climatic regions in Sweden (grey line). Four of the sites are also ICP sites (black-red dots). (Color figure online)

by disturbances, such as harvesting and storm damage. Nutrient availability is given by the nutrient concentrations in the soil solution. This concentration is the result of different processes: atmospheric deposition, hydrological transport, decomposition of organic matter, mineral weathering, adsorption and desorption in the soil and plant uptake. Water availability is given by the soil water content above wilting point at each time step. The soil moisture is calculated on a daily basis as the balance between water inputs (infiltration) and outputs (evapotranspiration, percolation).
ForSAFE is the combination of the algorithms of four established models (Fig. 2): the tree growth model PnET (Aber and Federer 1992), the soil chemistry model SAFE (Alveteg 1998), the decomposition model Decomp (Wallman et al. 2006; Walse et al. 1998), and the hydrology model PULSE (Lindström and Gardelin 1992).

\section{Model evaluation}

In this study, we avoided site specific adjustment of parameters used as input to the model to be able to better evaluate when the model is capable of describing correctly forest ecosystem processes and when further research is needed to improve model simulations. The identification of model strengths and weaknesses is the basis, on one hand, of identifying reliable results and, on the other hand, to highlight further research needs based on the identified weaknesses. The identified reliable information can be used to draw general conclusions on the effects of forest management intensification on base cations pools, which is useful for decision making.

Model results were evaluated against measurements available at the sites. The current tree biomass stocks at 5 sites were compared to measure-based values of tree biomass. The latter values were calculated based on Marklund's equations which convert measured tree diameter values to tree biomass (Marklund 1988). The comparison could not be done in Holmsvattnet where diameter data were not available, and the forest was recently clear-felled. We also compared the simulated nutrient content in the foliage to measured values in 1996-2006 at three sites where data were available (Västra Torup, Bordsjö and Högbränna). Finally, ForSAFE was also evaluated by comparing measured base cation concentrations in soil solution at $50-\mathrm{cm}$ depth to model results. The term "base cations" (BC) is this study includes magnesium, calcium and potassium, while it excludes sodium which is not a tree nutrient and therefore is not directly affected by forest management.

\section{Effects of forest management alternatives}

The future effects of forest management intensification were evaluated by comparing tree biomass and soil water chemistry at the sites in 2010-2100 under two alternative forest management scenarios: a stem harvesting scenario $(\mathrm{SH})$ and a whole-tree harvesting scenario (WTH). The timing of thinnings and clear-felling until 2100 reflects the historical management applied at the sites. When limited information on historical management was available, such as in Högbränna, we applied practices that are commonly recommended in the same region (Skogsstyrelsen 1985). The WTH includes the 
Table 1 Climate: mean annual temperature $\left(T_{\mathrm{m}}\right)$ and annual precipitation $(P)$ in 2010-2018 from the database PTHBV managed by SMHI (2006); Management: PL=planting year, $C C=$ last reported clear- felling; Productivity: mean annual increment calculated from tree diameter data converted to stem biomass with equations by Marklund (1988); n.a.: data not available

\begin{tabular}{|c|c|c|c|c|c|c|}
\hline Site & Region & Coordinates (Long, Lat) & Climate & Soil type & Management & $\begin{array}{l}\text { Productivity } \\
\left(\mathrm{m}^{3} \mathrm{ha}^{-1} \mathrm{yr}^{-1}\right)\end{array}$ \\
\hline Västra Torup & Southern Sweden & $13.51,56.14$ & $\begin{array}{l}\text { Tm: } 8.2^{\circ} \mathrm{C} \\
\text { P: } 831 \mathrm{~mm}\end{array}$ & $\begin{array}{l}\text { Brown podzolic soil, texture: sandy } \\
\text { loam }\end{array}$ & $\begin{array}{l}1940(\mathrm{PL}) \\
2010(\mathrm{CC})\end{array}$ & 6.7 \\
\hline Bordsjö & Southern Sweden & $15.00,57.84$ & $\begin{array}{l}\mathrm{Tm}: 6.4^{\circ} \mathrm{C} \\
\mathrm{P}: 714 \mathrm{~mm}\end{array}$ & Brown earth, texture: sand & $\begin{array}{l}1952(\mathrm{PL}) \\
\text { n.a. }(\mathrm{CC})\end{array}$ & 4.2 \\
\hline Södra Averstad & Central Sweden & $13.11,59.01$ & $\begin{array}{l}\text { Tm: } 7.3{ }^{\circ} \mathrm{C} \\
\text { P: } 731 \mathrm{~mm}\end{array}$ & $\begin{array}{l}\text { Brown podzolic soil, texture: loamy } \\
\text { sand }\end{array}$ & $\begin{array}{l}1931(\mathrm{PL}) \\
2016(\mathrm{CC})\end{array}$ & n.a \\
\hline Hyttskogen & Central Sweden & $16.54,59.91$ & $\begin{array}{l}\text { Tm: } 6.4{ }^{\circ} \mathrm{C} \\
\text { P: } 615 \mathrm{~mm}\end{array}$ & Brown earth, texture: sand & $\begin{array}{l}1957(\mathrm{PL}) \\
\text { n.a. }(\mathrm{CC})\end{array}$ & 1.6 \\
\hline Holmsvattnet & Northern Sweden & $21.05,64.54$ & $\begin{array}{l}\text { Tm: } 3.5^{\circ} \mathrm{C} \\
\text { P: } 723 \mathrm{~mm}\end{array}$ & Podzol soil, texture: sand & $\begin{array}{l}\text { n.a. (PL) } \\
2011(\mathrm{CC})\end{array}$ & n.a \\
\hline Högbränna & Northern Sweden & $18.10,65.41$ & $\begin{array}{l}\text { Tm: } 1.1^{\circ} \mathrm{C} \\
\text { P: } 682 \mathrm{~mm}\end{array}$ & Podzol soil, texture: sand & $\begin{array}{l}\text { n.a. }(\mathrm{PL}) \\
\text { n.a. }(\mathrm{CC})\end{array}$ & 1.3 \\
\hline
\end{tabular}

Fig. 2 Illustration of the interacting components of the ForSAFE model and the processes among them. The names of the original models combined in ForSAFE are reported in brackets. The model drivers are listed in the arrow on the left. (Color figure online)

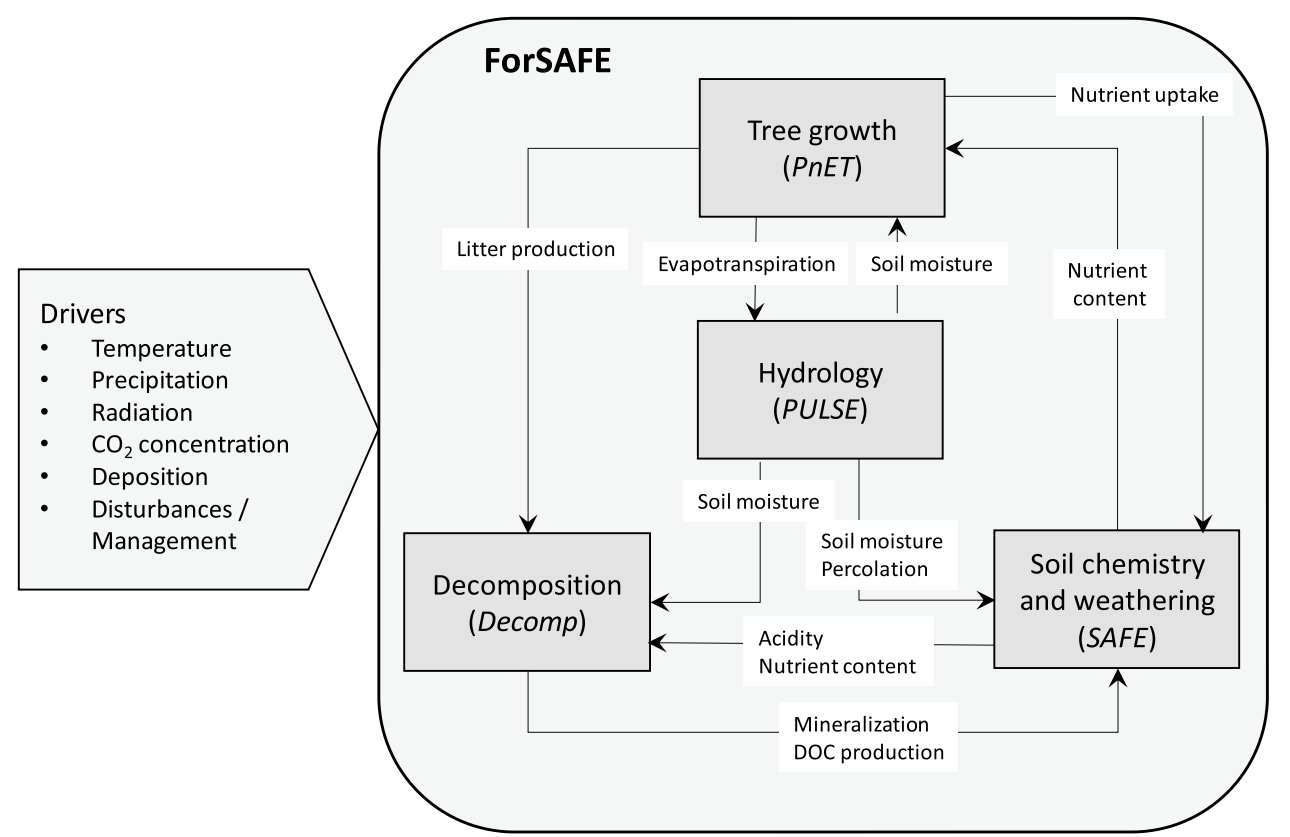

\section{Results}

\section{Model evaluation}

The simulated forest growth and tree biomass stocks were comparable with measure-based values at three sites where diameter data were available (Fig. 3). However, the model overestimated the tree biomass at Hyttskogen and underestimated it in Västra Torup. In Holmsvattnet, we could not evaluate the accuracy of the model in estimating tree 

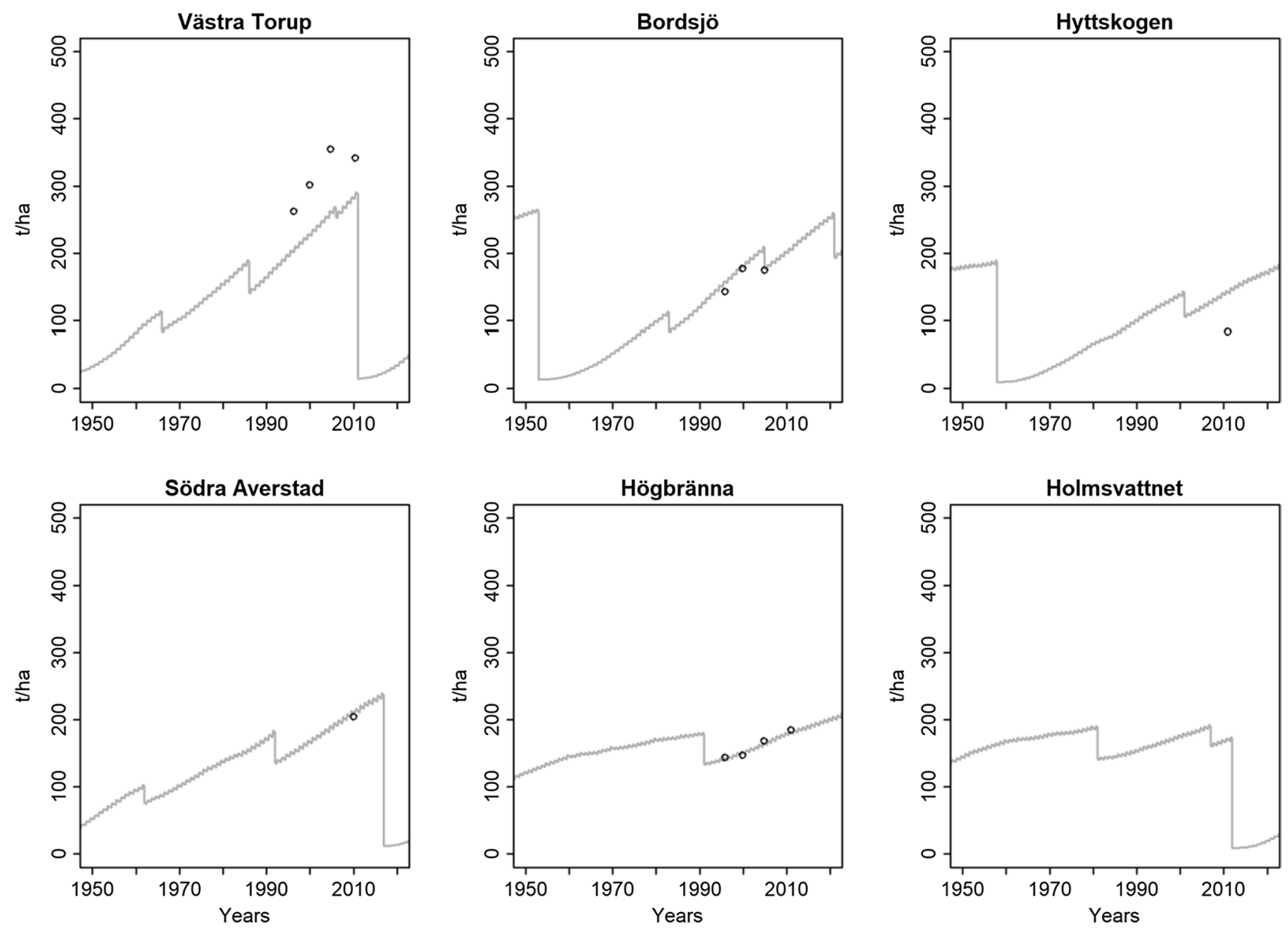

Fig. 3 Comparison of simulated (grey line) against measure-based tree biomass (points) at the different sites. (Color figure online)

Table 2 Measured and simulated nutrient contents in foliage, as average values in 1996-2006 (BC: base cations; N: nitrogen)

\begin{tabular}{llllll}
\hline & $\mathrm{BC}(\%)$ & & & $\mathrm{N}(\%)$ \\
\cline { 2 - 3 } \cline { 5 - 6 } \cline { 5 - 6 } & Measured & Modelled & & Measured & Modelled \\
\hline Västra Torup & $0.93 \pm 0.09$ & $1.13 \pm 0.00$ & & $1.30 \pm 0.11$ & $1.37 \pm 0.06$ \\
Bordsjö & $1.02 \pm 0.08$ & $1.11 \pm 0.01$ & & $1.30 \pm 0.10$ & $1.28 \pm 0.03$ \\
Högbranna & $1.13 \pm 0.15$ & $1.13 \pm 0.00$ & & $0.96 \pm 0.09$ & $1.08 \pm 0.01$ \\
\hline
\end{tabular}

The variation around the mean is given by the standard deviation. The data are reported as \% nutrient weight on dry needle weight

biomass due to lack of measurements. Nevertheless, the simulated tree growth and biomass were comparable to the other northern site in Högbranna.

The comparison of measured and simulated nutrient content in the needles showed that model results on nutrient storage in the canopy agreed with observations (Table 2). The main detected difference was that the model simulated very stable BC content across the sites while measurements show some slight variation between sites, with increasing content from South to North of Sweden. This measured trend is opposite to the $\mathrm{BC}$ deposition gradient in Sweden (Lövblad et al. 2000), and therefore, it is not related to higher $\mathrm{BC}$ atmospheric inputs but might be related to other factors, such as the type of bedrock or plant uptake. Regarding $\mathrm{N}$ contents, both the simulated and the measured values decreased with latitude, suggesting a decreasing nutrient availability from southern to northern forests compatible with the $\mathrm{N}$ deposition gradient in Sweden and the decreasing availability of nitrogen from southern to northern Sweden (Högberg et al. 2021).

The comparison of measured and modelled base cation concentrations in the soil solution at $50 \mathrm{~cm}$ ([BC]) shows 

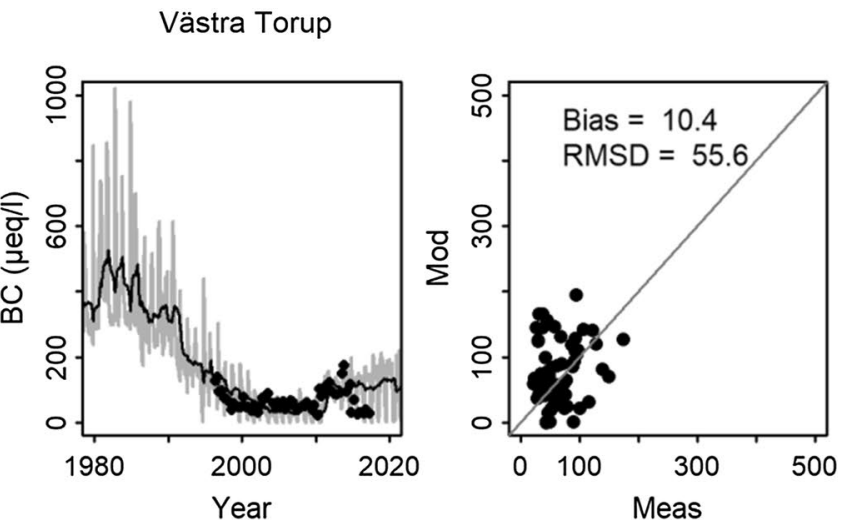

Hyttskogen

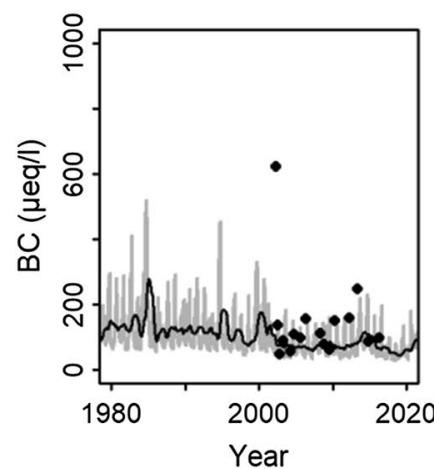

Högbranna
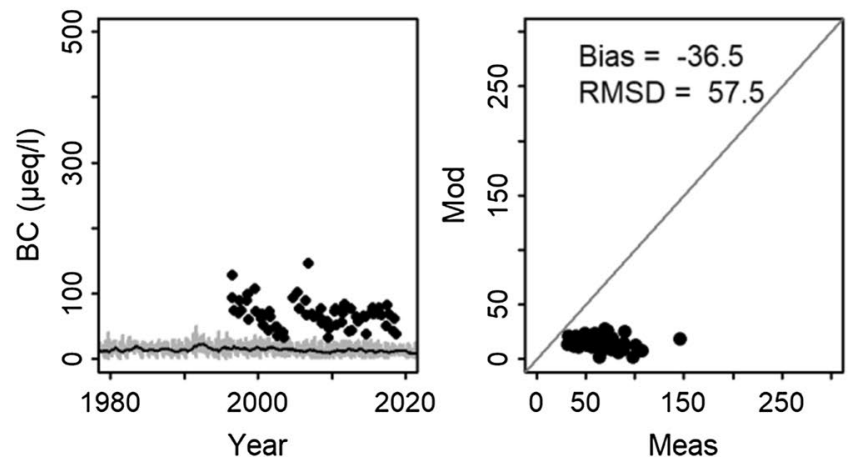

Fig. 4 Comparison of simulated against measured BC concentration in soil water at 50-cm-depth at the different sites. For each site, there are two types of graphs. In the first type, daily modelled results (grey line) and the moving average on a yearly basis (black line) are compared to measured data (points) over the years. In the second type of graph, the simulated and the measured value at the same point in time

that the model values were mostly comparable to measured $[\mathrm{BC}]$ in sites in southern and central Sweden (Fig. 4). In Hyttskogen, the statistical metrics indicated a model underestimation of $[\mathrm{BC}]$, which was mainly due to a very high measured value in 2002 in connection to the recent installation of lysimeters. However, [BC] was still underestimated if the outlier value was excluded. Discrepancies also existed
Bordsjö
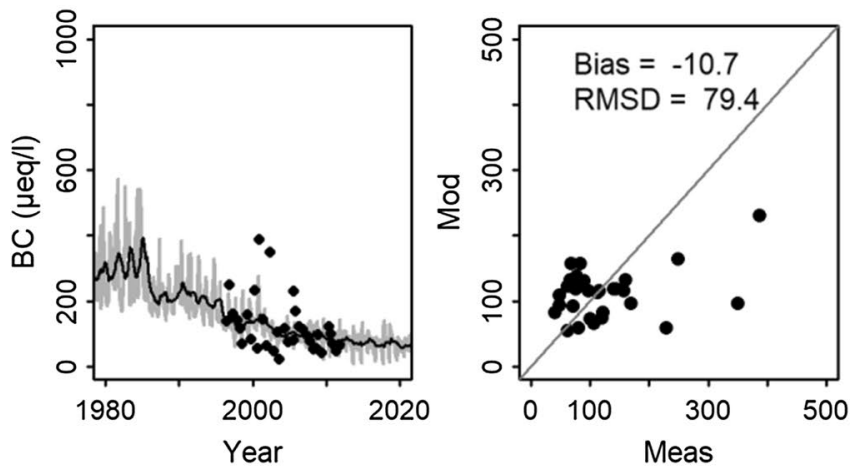

S Averstad
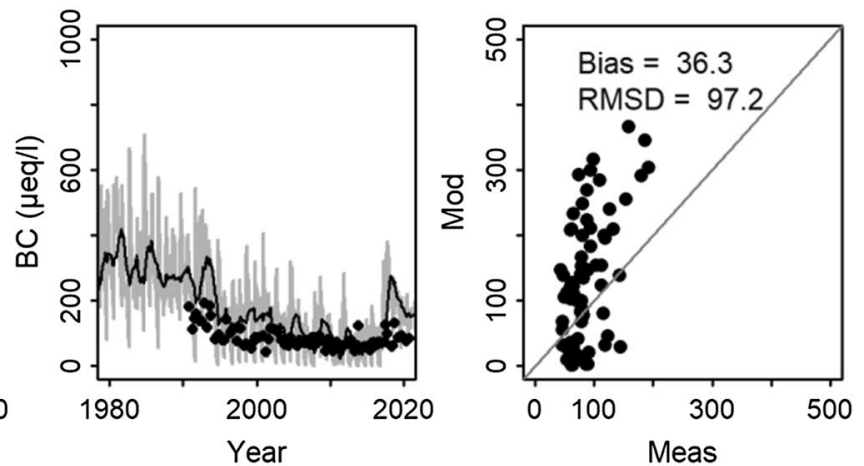

Holmsvattnet
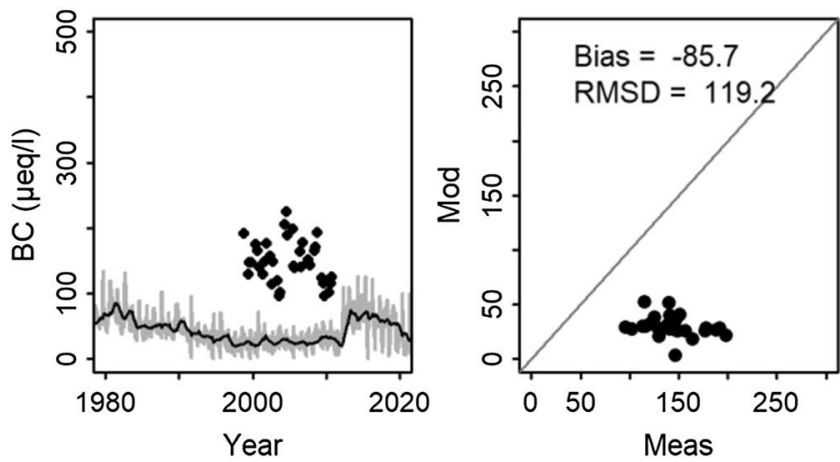

are plotted against each other. The discrepancy between simulated and measured data is assessed through two statistical metrics: Bias, which is the absolute average difference between the two data series and root-mean square deviation (RMSD) which aggregates the magnitudes of the errors in predictions. Note that the scales on the y axis differ between the two types of graph. (Color figure online)

in the simulation of dynamics, in terms of peaks and minimum values, which became evident when comparing values against a 1:1 line. Nonetheless, the model captured the long-term trends of $[\mathrm{BC}]$, such as decreases over time (more evident in Västra Torup and Södra Averstad) and changes after clear-felling, such as the temporary increase of $[\mathrm{BC}]$ in Västra Torup. Differently, the model failed to simulate the 
$[\mathrm{BC}]$ at the two northern sites, where modelled $[\mathrm{BC}]$ were substantially lower than measured values.

\section{Effects of forest management intensification}

The comparison of different management scenarios showed that the extraction of residues had a short-time effect on the simulated nutrient concentrations in the soil solution at all sites and reduced tree biomass growth in northern Sweden (Fig. 5).

Regarding base cations, residue extraction temporarily reduced the $[\mathrm{BC}]$ in the soil solution for a period of about 20-30 years and the difference could go up to $48 \%$ (Fig. 5; Table 3). The analysis of model results showed that this difference is caused by a higher simulated $\mathrm{BC}$ mineralisation from the soil organic matter pool under $\mathrm{SH}$, linked to the decomposition of residues left on the forest floor. Whereas, weathering rates of $\mathrm{BC}$ remained nearly unchanged (data not shown). The simulations also showed that residue extraction reduced $[\mathrm{BC}]$ for longer periods the further south the site is. In addition, at the two northern sites, after the initial period of 20 years, when [BC] was lower under the WTH scenario, [BC] became slightly higher under WTH than under SH. This shift was linked to a lower simulated BC uptake under WTH as compared to $\mathrm{SH}$ due to a reduced simulated tree growth in WTH under the same period of time (20-40 years after felling) (Figs. 5, 6).

The extraction of residues also temporarily reduced the $\mathrm{N}$ peak which is usually observed after clear-felling (Fig. 5) (Kubin 1998). As for [BC], this effect was linked to a lower simulated N mineralisation in WTH linked to the reduced litter inputs which resulted in lower simulated $\mathrm{N}$ concentrations in soil water.

Effects of WTH on tree biomass were seen only at the two northern sites. In areas with higher $\mathrm{N}$ deposition such as in southern and central Sweden, forest residue extraction did only produce a small decrease of simulated biomass growth, ranging between $3.8-5.4 \%$ difference at 40 years after clearfelling. At the northern sites, Högbränna and Holmsvattnet, the simulated tree biomass was $15.9 \%$ and $26.9 \%$ lower 30 years after clear-felling under WTH. However, this difference was smaller 40 years after clear-felling: $7.3 \%$ lower in Högbranna and $18.3 \%$ in Holmsvattnet. At the end of the simulation period in 2100 , the tree biomass difference was reduced to $1.3 \%$ in Högbranna and $1.6 \%$ in Holmsvattnet (Fig. 6). When the forest was more mature, the simulated tree growth slowed down at similar rates under both management scenarios because of canopy closure which limits light absorption in mature forests. That is, the canopy closed more rapidly under SH because of the faster growth linked to higher $\mathrm{N}$ availability, as shown by the lower under-canopy light earlier than under the WTH scenario (Fig. 6). As a counterpart, the forest keep growing at higher rates under WTH for a longer period of time until canopy closure was also reached. As a consequence, the biomass reached similar biomass levels under both scenarios at a later maturity stage.

\section{Discussion}

\section{Model limitations}

Based on the results of the model validation, the main model limitations identified in this study are connected to a mismatch between simulated and measure-based biomass at some of the sites and the underestimation of [BC] concentrations in soil water at the northern sites.

We hypothesize that the difference between simulated and measure-based tree biomass in Hyttskogen and Västra Torup was caused by a mismatch between actual and simulated water limitation at the two sites. The soil in Hyttskogen is very sandy and has a large fraction of gravel $(50 \%$ of soil weight excluding stones) and stones (60\% of total soil volume) which are conditions often linked to low water availability. In addition, there was a limited number of measurements of soil water chemistry at Hyttskogen, because the soil water content was below the threshold for taking samples. This further supports the hypothesis that the site had low water availability. The model simulated a slower tree growth than at other sites, but probably failed to fully capture the extent to which such extreme soil conditions can affect tree growth. Conversely, it is possible that the underestimation of biomass in Västra Torup was partially linked to an overestimated effect of water limitation in Västra Torup (Lucander et al. 2021). In ForSAFE water-use efficiency is regulated by $\mathrm{CO}_{2}$ concentration, vapour pressure deficit and a constant which was shown to vary depending on site conditions such as leaf area index and soil water content (Aber and Federer 1992; Beer et al. 2009). Therefore, future research should better investigate the parameters and functions regulating tree water use in ForSAFE. A study by Lu and Zhuang (2010) confirms that there is a general need to improve the mechanisms describing water-use efficiency in ecosystem modelling, since this efficiency does not constantly increase in response to water stress.

The model underestimated the $[\mathrm{BC}]$ in soil water at the northern sites. There are two possible explanations which combined can explain why the model failed to fully capture the $[\mathrm{BC}]$ in the North. First, the historical BC deposition used as input data in the model might be underestimated, 

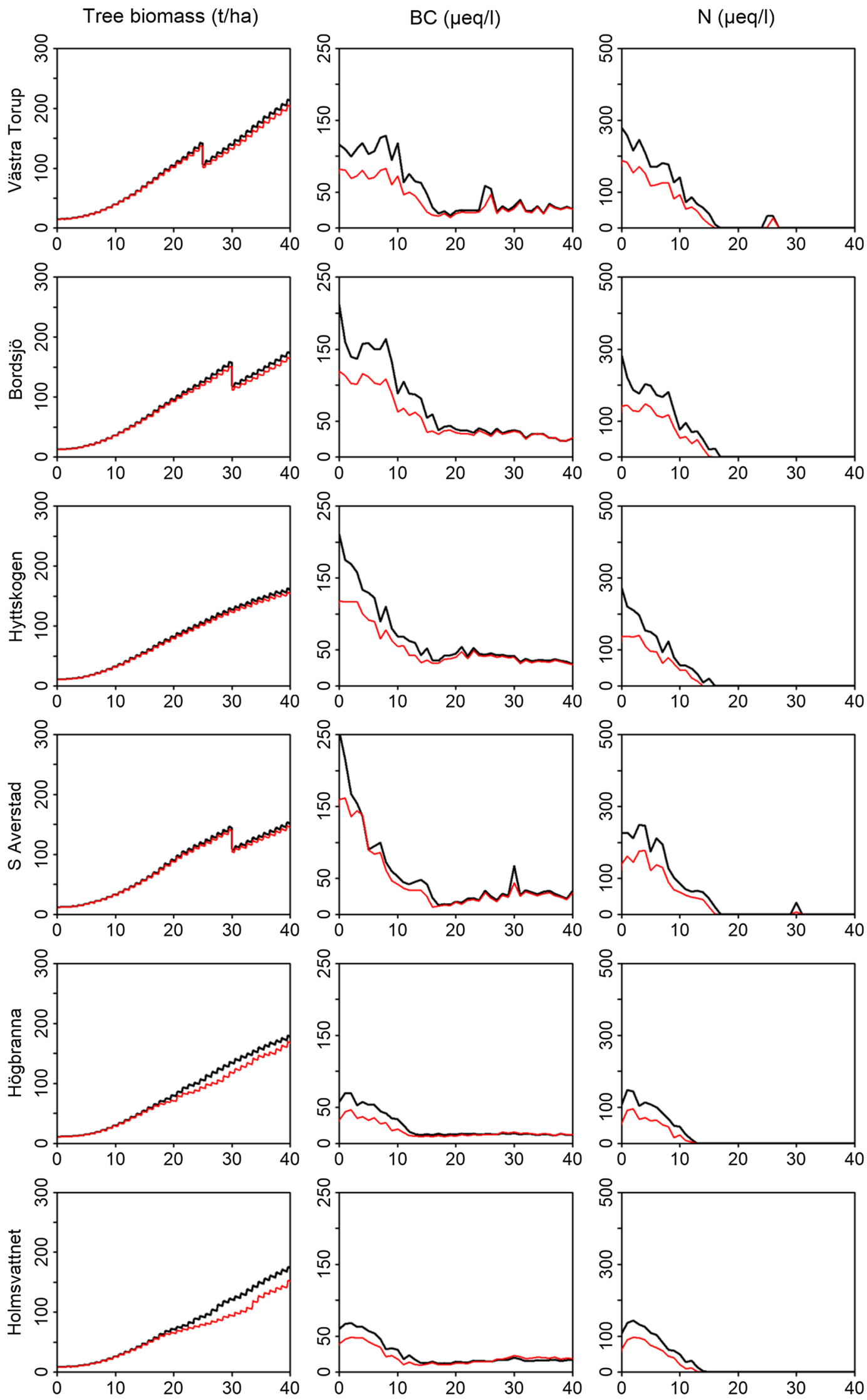
४Fig. 5 Effect of whole-tree harvesting (red line) and stem harvesting (black line) on tree biomass, base cation (BC) concentrations and nitrogen $(\mathrm{N})$ concentrations in soil water over a time period of 40 years after clear-felling. (Color figure online)

leading to an underestimation of current $\mathrm{BC}$ content in the soil pools. The BC deposition used as input to ForSAFE was a constant value equal to the average measured $\mathrm{BC}$ deposition at the sites since the 1990 or later. However, Hedin et al. (1994) showed that BC deposition significantly declined in the 1970-1990s at several sites in North America and Europe, supporting the hypothesis that $\mathrm{BC}$ inputs in the model can be historically underestimated. Second the current simulations might underestimate $\mathrm{BC}$ uptake in northern sites, thereby understating the importance of the biological cycle in retaining $\mathrm{BC}$ in the ecosystem over time. Literature shows significant differences between general allometric nutrient contents used in modelling and site specific values of BC concentrations in tree woody tissue (Tremblay et al. 2012). This issue can be further exacerbated by the fact that broad-leaf deciduous trees, which have higher $\mathrm{Mg}$ and $\mathrm{K}$ concentrations in foliage (Alriksson and Eriksson 1998), are often more present in northern forest stands and are currently not included in model simulations. Moreover, the model currently simulates an aggregated BC uptake by trees limiting the possibility to capture the variation of different $\mathrm{BC}$ availability at different sites. This simplification can also be the reason why the different $\mathrm{BC}$ concentration in needles showed by measurements was not captured by the model.

\section{Effects of forest management intensification}

The model simulate a temporary reduction of $\mathrm{BC}$ concentrations in soil solution ([BC]) for a period of about 20-30 years after WTH and greatest effects in the first 10 years after clear-felling (Fig. 5; Table 3), which is in line with observation at experimental sites (Achat et al. 2015; Ring et al. 2017; Zetterberg et al. 2013). This negative effect persisted for a longer period of times at sites in southern Sweden supporting research results showing greater effects of WTH in warmer climates (Clarke et al. 2021). These results are encouraging, since they can lead to an improved agreement between model simulations and measurements, as compared to previous model estimates that assessed longer negative effects of WTH on the BC pools in the soil and the acidity of surface water (Aherne et al. 2012; Zetterberg et al. 2014). In addition, in agreement with other studies, they stress the importance of including processes such as weathering and vegetation in model simulations to capture the effect of management intensification on BC cycling (Erlandsson Lampa et al. 2020; Paré and Thiffault 2016).

The model also suggested that none of the sites was currently $\mathrm{BC}$ limited, given that the $\mathrm{BC}$ contents in needles were close to the maximum value allowed in the model. These results are compatible with the fertilisation experiments that showed a non-significant change of forest growth after ash fertilisation only, but positive responses to combined $\mathrm{N}$ and ash fertilisation (Jacobson et al. 2014). However, it should be considered that under a continuous management intensification, $\mathrm{BC}$ availability in forest ecosystems could be progressively reduced, with possible risks for reduced soil fertility and forest productivity over periods longer than a rotation period (Vangansbeke et al. 2015; Walmsley et al. 2009). Negative effects on nutrient availability could also increase if residues are extracted not only after clear-felling but also after thinnings. However, the effects of whole-tree thinning on $\mathrm{BC}$ can differ depending on the cation and the soil compartment (Clarke et al. 2021), and the effects on tree growth are not consistent among studies (Jacobson et al. 2000; Lim et al. 2020).

Effects on tree growth were simulated only at northern sites where $\mathrm{N}$ deposition was historically low and which therefore are more $\mathrm{N}$ deficient (Binkley and Högberg 2016). The model results on tree growth are consistent with experimental results in spruce forests in southern and central Sweden, showing no significant effects of WTH on standing volume (Egnell 2016) and tree growth reduction at N-poor sites (Jacobson et al. 2000; Proe et al. 1996). That is, residue extraction can further reduce $\mathrm{N}$ availability at $\mathrm{N}$-poor sites and therefore potentially reduce forest growth, unless $\mathrm{N}$ fertilisation is performed or foliage is left on site (Egnell 2011; Jacobson 2001). The results in this study showed that WTH reduced the well-known temporary N peak occurring after clear-felling (Likens et al. 1970), confirming a reduction of N availability after WTH. This is in agreement with experimental studies showing a decrease of $\mathrm{N}$ stock in the soil and of $\mathrm{N}$ concentrations in the soil solution after WTH (Clarke et al. 2021; Hume et al. 2018; Ring et al. 2017). The reduction of the N peak after WTH also has the positive effect of reducing the risk of $\mathrm{N}$ leaching after clear-felling. However, it was shown that this positive effect is outweighed by the losses from residues extraction that are more important for the longer-term site nutrient status (Stevens et al. 1995; Walmsley et al. 2009).

The simulated effects on tree biomass at $\mathrm{N}$ limited sites decreased over time suggesting that the effect of WTH on tree biomass might be temporary. After the decrease of tree biomass after WTH caused by lower N availability, other limiting factors dominated tree growth at a later maturity 
Table 3 Difference of BC concentration in soil water under stem $(\mathrm{SH})$ and whole-tree (WTH) harvesting at different sites $10,20,30$ and 40 years after harvesting

\begin{tabular}{|c|c|c|c|c|c|}
\hline $\begin{array}{l}\text { Years after clear- } \\
\text { felling }\end{array}$ & Site & $\mathrm{SH}\left(\mu \mathrm{eq} \mathrm{l}^{-1}\right)$ & WTH $\left(\mu\right.$ eq $\left.1^{-1}\right)$ & Difference $(\%)$ & Significance \\
\hline \multirow[t]{6}{*}{10} & VT & $94.5 \pm 72.6$ & $60.3 \pm 57.1$ & -36.2 & $* * *$ \\
\hline & BS & $132.2 \pm 68.1$ & $88.4 \pm 54$ & -33.1 & $* * *$ \\
\hline & HS & $79.4 \pm 38.3$ & $63.4 \pm 31.3$ & -20.2 & $* * *$ \\
\hline & SA & $59.7 \pm 43.4$ & $46.4 \pm 38.9$ & -22.2 & $* * *$ \\
\hline & $\mathrm{HB}$ & $34.6 \pm 20.4$ & $17.8 \pm 10$ & -48.4 & $* * *$ \\
\hline & $\mathrm{HV}$ & $33.2 \pm 29.4$ & $22.9 \pm 23.9$ & -31.2 & $* * *$ \\
\hline \multirow[t]{6}{*}{20} & VT & $17.8 \pm 14.9$ & $14.8 \pm 12.9$ & -16.9 & $* *$ \\
\hline & BS & $43.3 \pm 14.8$ & $37.6 \pm 12.7$ & -13.1 & $* * *$ \\
\hline & HS & $42.6 \pm 9$ & $37.9 \pm 7$ & -10.9 & $* * *$ \\
\hline & SA & $13.9 \pm 12.2$ & $12.3 \pm 10.5$ & -12.1 & $\mathrm{~ns}$ \\
\hline & $\mathrm{HB}$ & $12.9 \pm 20.4$ & $10.7 \pm 5.8$ & -17.2 & $* * *$ \\
\hline & HV & $12.1 \pm 4.7$ & $10.5 \pm 4$ & -12.8 & $* * *$ \\
\hline \multirow[t]{6}{*}{30} & VT & $25.1 \pm 22$ & $22.7 \pm 20.9$ & -9.4 & ns \\
\hline & BS & $35.8 \pm 12.2$ & $34 \pm 11.3$ & -5 & $* * *$ \\
\hline & HS & $41.7 \pm 7.6$ & $39.3 \pm 6.7$ & -5.9 & $* * *$ \\
\hline & SA & $25.7 \pm 23.4$ & $23.9 \pm 22$ & -6.9 & ns \\
\hline & $\mathrm{HB}$ & $13.1 \pm 5.9$ & $14.1 \pm 5.8$ & 7.6 & $*$ \\
\hline & $\mathrm{HV}$ & $17.3 \pm 6.4$ & $20.2 \pm 6$ & 16.7 & $* * *$ \\
\hline \multirow[t]{6}{*}{40} & VT & $29.9 \pm 19.6$ & $28.7 \pm 19.4$ & -4.2 & ns \\
\hline & BS & $22.7 \pm 9.8$ & $23.1 \pm 9.8$ & 1.7 & $\mathrm{~ns}$ \\
\hline & HS & $33.7 \pm 7.8$ & $31.9 \pm 6.6$ & -5.2 & $* * *$ \\
\hline & SA & $21.9 \pm 20.8$ & $20.2 \pm 19.4$ & -7.8 & ns \\
\hline & $\mathrm{HB}$ & $11.3 \pm 4.3$ & $11.9 \pm 4.2$ & 5.8 & $*$ \\
\hline & HV & $17.1 \pm 11.1$ & $19.6 \pm 12.1$ & 15 & $* *$ \\
\hline
\end{tabular}

The data at different points in time reported are: mean BC concentration and standard deviation; percentage difference of $\mathrm{BC}$ concentration under $\mathrm{WTH}$ and $\mathrm{SH}$, i.e. $(\mathrm{WTH}-\mathrm{SH}) / \mathrm{SH} \times 100$; statistical significance of the difference (ns: $P>0.05 ; * P \leq 0.05 ; * * P \leq 0.01$, ***P $\leq 0.001$ ). The significance was tested through Wilcoxon signed-rank test for non-normally distributed samples)

$V T$ Västra Torup, BS Bordsjö, $H S$ Hyttskogen, $S A$ Södra Averstad, $H B$ Högbränna, $H V$ Holmsvattnet stage. Vanguelova et al. (2010) showed that WTH decreased tree growth, but after a period of 15-20 years the trees grew at similar rates as after $\mathrm{SH}$. The results also agree with (Egnell 2011) that showed that reduction of site productivity after WTH was temporary and linked to increased N losses from residue extraction. Future measurements in the whole-tree harvesting experiments would be needed to confirm this simulated shrinkage of the biomass gap. The modelling results might also change if more than one rotation period is considered. WTH might progressively reduce $\mathrm{N}$ availability and thereby increase the $\mathrm{N}$ limitation period when trees grow slower than under SH. This would lead to the situation where the forest would not be able to reach the same biomass stock as under the SH scenario at the end of the rotation period.

\section{Conclusions}

The study results confirmed that whole-tree harvesting can temporarily reduce the base cation concentration in soil water for a period of 20-30 years, in agreement with experimental data. This effect is linked to the reduced inputs of organic material which lead to reduced nutrient mineralisation in the soil. Therefore, it can be expected that the more intensive residue extraction is in terms of total biomass extracted and the frequency of extraction, the more reduced the base cation availability will be by whole-tree harvesting, with possible consequences on acidification. However, results also suggested that base cations do not currently limit forest growth at any of the sites and that the temporary decrease of base cation availability after residue extraction would not limit forest growth within the next rotation period.

Nevertheless, results showed that whole-tree harvesting can affect tree growth at nitrogen limited forest sites, such 

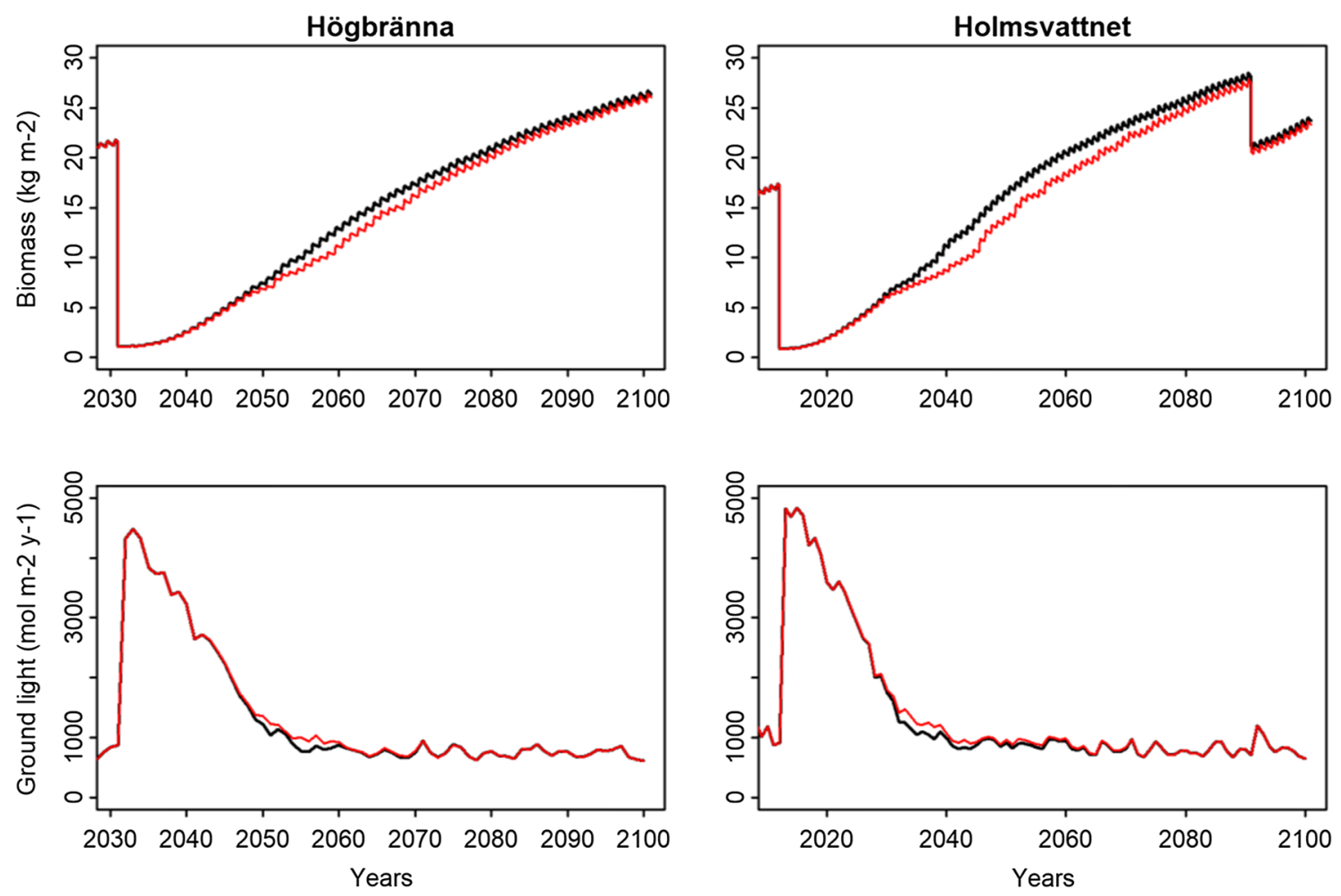

Fig. 6 Effect of whole-tree harvesting (red line) and stem harvesting (black line) over a rotation period on tree biomass and on under-canopy light. (Color figure online)

as the ones in northern Sweden. Whole-tree harvesting had a similar effect on nitrogen as on base cation concentrations in soil water. As a consequence, nitrogen availability was further reduced by residue extraction and lead to a slower forest growth at northern sites. A possible way of reducing this impact is to compensate the losses with nitrogen fertilisation or extract residue without foliage in areas of Sweden with low nitrogen deposition.

The study also highlighted the need to better understand the medium- and long-term effects of whole-tree harvesting on tree growth. The results suggested that over a rotation period, other limiting factors might level up the earlier difference in tree growth under stem and whole-tree harvesting. On the other hand, there is a concrete risk that prolonged extraction of forest residues will progressively deplete nutrient pools in the forest ecosystems and increase the period of slower tree growth after whole-tree harvesting. As a consequence, the biomass difference could become permanent. Given that even long-term experiments do not provide data for periods longer than 50 years, it is fundamental to promote studies combining measurements with model simulations to evaluate the long-term sustainability of residue extraction.
Funding Open access funding provided by Lund University. This work was supported by the Swedish Energy Agency [project number: 482421] and the strategic research area BECC (becc.lu.se) which have jointly financed the research presented in this paper.

Data availability Soil and biomass were derived from the data collected at the Swedish Throughfall Monitoring Network (SWETHRO). Part of the data is available on the web-site (https://krondroppsnatet. ivl.se/), and part of the data is available upon request to IVL, the Environment Institute managing the SWETHRO network or to the authors of the paper. Climate and deposition data for the past and the future were derived from simulations by SMHI (Swedish Meteorological and Hydrological Institute), as described in the Methods section. For these data, we refer to SMHI, in their role as data host for the data. Measured deposition and soil solution chemistry from recent years were obtained from data downloadable at https://krondroppsnatet.ivl.se/.

Code availability The code of the ForSAFE model is freely available upon request to the model developers: salim.belyazid@natgeo.su.se; giuliana.zanchi@nateko.lu.se. Previous collaborations with other research groups have shown that new users need an initial period of guidance to be able to independently run the model. Therefore, an initial period of collaboration with the model developers is encouraged with the intent to support new user in the initial stage of their work with the ForSAFE model. 


\section{Declarations}

Conflict of interest The authors declare no conflict of interest. The funders had no role in the design of the study; in the collection, analyses, or interpretation of data; in the writing of the manuscript, or in the decision to publish the results.

Open Access This article is licensed under a Creative Commons Attribution 4.0 International License, which permits use, sharing, adaptation, distribution and reproduction in any medium or format, as long as you give appropriate credit to the original author(s) and the source, provide a link to the Creative Commons licence, and indicate if changes were made. The images or other third party material in this article are included in the article's Creative Commons licence, unless indicated otherwise in a credit line to the material. If material is not included in the article's Creative Commons licence and your intended use is not permitted by statutory regulation or exceeds the permitted use, you will need to obtain permission directly from the copyright holder. To view a copy of this licence, visit http://creativecommons.org/licenses/by/4.0/.

\section{References}

Aber JD, Federer CA (1992) A generalized, lumped-parameter model of photosynthesis, evapotranspiration and net primary production in temperate and boreal forest ecosystems. Oecologia 92:463-474. https://doi.org/10.1007/bf00317837

Alveteg M (1998) Dynamics of Forest Soil Chemistry. Doctoral thesis. Lund University, Lund, Sweden, pp 81

Achat DL, Deleuze C, Landmann G, Pousse N, Ranger J, Augusto L (2015) Quantifying consequences of removing harvesting residues on forest soils and tree growth - a meta-analysis. For Ecol Manage 348:124-141. https://doi.org/10.1016/j.foreco.2015.03.042

Aherne J, Posch M, Forsius M, Lehtonen A, Härkönen K (2012) Impacts of forest biomass removal on soil nutrient status under climate change: a catchment-based modelling study for Finland. Biogeochemistry 107:471-488. https://doi.org/10.1007/ s10533-010-9569-4

Akselsson C et al (2021) A combined measurement and modelling approach to assess the sustainability of whole-tree harvesting - a swedish case study. Sustainability 13:2395

Alriksson A, Eriksson HM (1998) Variations in mineral nutrient and C distribution in the soil and vegetation compartments of five temperate tree species in NE Sweden. For Ecol Manage 108:261-273. https://doi.org/10.1016/S0378-1127(98)00230-8

Beer C et al (2009) Temporal and among-site variability of inherent water use efficiency at the ecosystem level. Global Biogeochem Cycles 23:GB2018. https://doi.org/10.1029/2008GB003233

Binkley D, Högberg P (2016) Tamm review: revisiting the influence of nitrogen deposition on Swedish forests For Ecol. Manage 368:222-239. https://doi.org/10.1016/j.foreco.2016.02.035

Brandtberg P-O, Olsson B (2012) Changes in the effects of whole-tree harvesting on soil chemistry during 10 years of stand development. For Ecol Manage 277:150-162. https://doi.org/10.1016/j. foreco.2012.04.019

Clarke $\mathrm{N}$ et al (2021) Effects of intensive biomass harvesting on forest soils in the Nordic countries and the UK: a meta-analysis. For Ecol Manage 482:118877. https://doi.org/10.1016/j.foreco. 2020.118877

de Jong J, Akselsson C, Egnell G, Löfgren S, Olsson BA (2017) Realizing the energy potential of forest biomass in Sweden-how much is environmentally sustainable? For Ecol Manage 383:3-16. https://doi.org/10.1016/j.foreco.2016.06.028
Egnell G (2011) Is the productivity decline in Norway spruce following whole-tree harvesting in the final felling in boreal Sweden permanent or temporary? For Ecol Manage 261:148-153. https:// doi.org/10.1016/j.foreco.2010.09.045

Egnell G (2016) Effects of slash and stump harvesting after final felling on stand and site productivity in Scots pine and Norway spruce. For Ecol Manage 371:42-49. https://doi.org/10.1016/j.foreco. 2016.03.006

Erlandsson LM, Belyazid S, Zanchi G, Akselsson C (2019) Effects of whole-tree harvesting on soil, soil water and tree growth-a dynamic modelling exercise in four long-term experiments. Ecol Model 414:108832. https://doi.org/10.1016/j.ecolmodel.2019. 108832

Erlandsson Lampa M, Sverdrup HU, Bishop KH, Belyazid S, Ameli A, Köhler SJ (2020) Catchment export of base cations: improved mineral dissolution kinetics influence the role of water transit time. SOIL 6:231-244. https://doi.org/10.5194/soil-6-231-2020

Hedin LO, Granat L, Likens GE, Adri Buishand T, Galloway JN, Butler TJ, Rodhe H (1994) Steep declines in atmospheric base cations in regions of Europe and North America. Nature 367:351-354

Högberg P, Wellbrock N, Högberg MN, Mikaelsson H, Stendahl J (2021) Large differences in plant nitrogen supply in German and Swedish forests-implications for management. For Ecol Manage 482:118899. https://doi.org/10.1016/j.foreco.2020.118899

Hume AM, Chen HYH, Taylor AR (2018) Intensive forest harvesting increases susceptibility of northern forest soils to carbon, nitrogen and phosphorus loss. J Appl Ecol 55:246-255. https:// doi.org/10.1111/1365-2664.12942

Jacobson S (2001) Fertilization to increase and sustain tree growth in coniferous stands in Sweden. ISBN 91-576-6301-7 SLU

Jacobson S, Kukkola M, Mälkönen E, Tveite B (2000) Impact of whole-tree harvesting and compensatory fertilization on growth of coniferous thinning stands. For Ecol Manage 129:41-51. https://doi.org/10.1016/S0378-1127(99)00159-0

Jacobson S, Lundström H, Nordlund S, Sikström U, Pettersson F (2014) Is tree growth in boreal coniferous stands on mineral soils affected by the addition of wood ash? Scand J for Res 29:675-685. https://doi.org/10.1080/02827581.2014.959995

Johnson J, Aherne J, Cummins T (2015) Base cation budgets under residue removal in temperate maritime plantation forests. For Ecol Manage 343:144-156. https://doi.org/10.1016/j.foreco. 2015.01.022

Kimmins JP (1976) Evaluation of the consequences for future tree productivity of the loss of nutrients in whole-tree harvesting. For Ecol Manage 1:169-183. https://doi.org/10.1016/03781127(76)90019-0

Kreutzweiser DP, Hazlett PW, Gunn JM (2008) Logging impacts on the biogeochemistry of boreal forest soils and nutrient export to aquatic systems: a review. Environ Rev 16:157-179. https:// doi.org/10.1139/A08-006

Kubin E (1998) Leaching of nitrate nitrogen into the groundwater after clear felling and site preparation Boreal. Environ Res $3: 3-8$

Likens GE, Bormann FH, Johnson NM, Fisher DW, Pierce RS (1970) Effects of forest cutting and herbicide treatment on nutrient budgets in the hubbard brook watershed-ecosystem. Ecol Monogr 40:23-47. https://doi.org/10.2307/1942440

Lindström G, Gardelin M (1992) Chapter 3.1: Hydrological modelling - Model structure. In Modelling groundwater response to acidification. In: Sandén P, Wärfvinge P (eds) Norrköping, SMHI, Reports Hydrology

Lim H, Olsson BA, Lundmark T, Dahl J, Nordin A (2020) Effects of whole-tree harvesting at thinning and subsequent compensatory nutrient additions on carbon sequestration and soil acidification 
in a boreal forest GCB. Bioenergy 12:992-1001. https://doi.org/ $10.1111 /$ gcbb. 12737

Lindner $\mathrm{M}$ et al (2017) Chapter 6-assessing lignocellulosic biomass potentials from forests and industry. In: Panoutsou C (ed) Modeling and optimization of biomass supply chains. Academic Press, pp 127-167. doi:https://doi.org/10.1016/B978-0-12812303-4.00006-9

Löfgren S, Ågren A, Gustafsson JP, Olsson BA, Zetterberg T (2017) Impact of whole-tree harvest on soil and stream water acidity in southern Sweden based on HD-MINTEQ simulations and pH-sensitivity. For Ecol Manage 383:49-60. https://doi.org/10. 1016/j.foreco.2016.07.018

Lövblad G, Persson C, Roos E (2000) Deposition of base cations in Sweden vol Report 5119. Swedish Environmental Protection Agency Trelleborg

Lu X, Zhuang Q (2010) Evaluating evapotranspiration and water-use efficiency of terrestrial ecosystems in the conterminous United States using MODIS and AmeriFlux data. Remote Sens Environ 114:1924-1939. https://doi.org/10.1016/j.rse.2010.04.001

Lucander K, Zanchi G, Akselsson C, Belyazid S (2021) The effect of nitrogen fertilization on tree growth, soil organic carbon and nitrogen leaching - a modeling study in a steep nitrogen deposition gradient in Sweden Forests 12:298

Marklund LG (1988) Biomassafunktioner för tall, gran och björk i Sverige vol Rapport 45. Sveriges lantbruksuniversitet, Institutionen för skogstaxering,

Ouimet R, Duchesne L, Tremblay S (2021) Long-term soil fertility and site productivity in stem-only and whole-tree harvested stands in Boreal Forest of Quebec (Canada). Forests 12:583

Paré D, Thiffault E (2016) Nutrient budgets in forests under increased biomass harvesting scenarios current forestry reports 2:81-91 doi:https://doi.org/10.1007/s40725-016-0030-3

Pihl Karlsson G, Akselsson C, Hellsten S, Karlsson PE (2011) Reduced European emissions of $\mathrm{S}$ and $\mathrm{N}$-effects on air concentrations, deposition and soil water chemistry in Swedish forests. Environ Pollut 159:3571-3582. https://doi.org/10.1016/j.envpol.2011.08. 007

Premer MI, Froese RE, Vance ED (2019) Whole-tree harvest and residue recovery in commercial aspen: Implications to forest growth and soil productivity across a rotation. For Ecol Manage 447:130 138. https://doi.org/10.1016/j.foreco.2019.05.002

Proe MF, Cameron AD, Dutch J, Christodoulou XC (1996) The effect of whole-tree harvesting on the growth of second rotation Sitka spruce. For Int J for Res 69:389-401. https://doi.org/10.1093/fores try/69.4.389

PTHBV: Klimatdatabas förhydrologiska beräkningar (2006) SMHI.

Raulund-Rasmussen K, Stupak I, Clarke N, Callesen I, Helmisaari H-S, Karltun E, Varnagiryte-Kabasinskiene I (2008) Effects of very intensive forest biomass harvesting on short and long term site productivity. In: Röser D, Asikainen A, Raulund-Rasmussen K, Stupak I (eds) Sustainable use of forest biomass for energy: a synthesis with focus on the Baltic and Nordic Region. Springer Netherlands, Dordrecht, pp 29-78. doi:https://doi.org/10.1007/ 978-1-4020-5054-1_3

Ring E, Jacobson S, Jansson G, Högbom L (2017) Effects of whole-tree harvest on soil-water chemistry at five conifer sites in Sweden. Can J for Res 47:349-356. https://doi.org/10.1139/cjfr-2016-0338

SEPA (2016) Climate change and the Environmental objectivesCLEO, vol 6705. Bromma, Sweden

SKA (2015) Skogliga konsekvensanalyser 2015-SKA15, vol 10. Skogsstyrelsen, Jönköping

Skogsstyrelsen (1985) Gallringsmallar Norra Sverige, vol Art. n. 64. Skogsstyrelsen, Jönköping

Stevens PA et al (1995) Nutrient losses after clearfelling in Beddgelert Forest: a comparison of the effects of conventional and whole-tree harvest on soil water chemistry. For Int J for Res 68:115-131. https://doi.org/10.1093/forestry/68.2.115

Swedish Energy Agency (2011) Energimyndighetens roll i miljömålssystemet. Eskilstuna, Sweden

Swedish Energy Agency (2014) Consequences of an increased extraction of forest biofuel in Sweden - a synthesis from the bioenergy feedstock research programme 2007-2011, supported by Swedish Energy Agency, vol ER 2014:09. Swedish Energy Agency, Eskilstuna, Sweden

Thiffault E, Hannam KD, Paré D, Titus BD, Hazlett PW, Maynard DG, Brais S (2011) Effects of forest biomass harvesting on soil productivity in boreal and temperate forests-a review. Environ Rev 19:278-309. https://doi.org/10.1139/a11-009

Tremblay S, Ouimet R, Houle D, Duchesne L (2012) Base cation distribution and requirement of three common forest ecosystems in eastern Canada based on site-specific and general allometric equations. Can J Res 42:1796-1809. https://doi.org/10.1139/ x2012-125

Valipour M, Driscoll CT, Johnson CE, Battles JJ, Campbell JL, Fahey TJ (2018) The application of an integrated biogeochemical model to simulate dynamics of vegetation, hydrology and nutrients in soil and streamwater following a whole-tree harvest of a northern hardwood forest. Sci Total Environ 645:244-256. https://doi.org/ 10.1016/j.scitotenv.2018.07.066

Vangansbeke P, De Schrijver A, De Frenne P, Verstraeten A, Gorissen L, Verheyen K (2015) Strong negative impacts of whole tree harvesting in pine stands on poor, sandy soils: a long-term nutrient budget modelling approach. For Ecol Manage 356:101-111. https://doi.org/10.1016/j.foreco.2015.07.028

Vanguelova E, Pitman R, Luiro J, Helmisaari H-S (2010) Long term effects of whole tree harvesting on soil carbon and nutrient sustainability in the UK. Biogeochemistry 101:43-59. https://doi.org/ 10.1007/s10533-010-9511-9

Walse C, Berg B, Sverdrup H (1998) Review and synthesis of experimental data on organic matter decomposition with respect to the effect of temperature, moisture, and acidity. Environ Rev 6:25-40

Wallman P, Belyazid S, Svensson MGE, Sverdrup H (2006) DECOMP - a semi mechanistic model of litter decomposition. Environ Model \& Softw 21:33-44

Walmsley JD, Jones DL, Reynolds B, Price MH, Healey JR (2009) Whole tree harvesting can reduce second rotation forest productivity. For Ecol Manage 257:1104-1111. https://doi.org/10.1016/j. foreco.2008.11.015

Zetterberg T, Olsson BA, Löfgren S, von Brömssen C, Brandtberg P-O (2013) The effect of harvest intensity on long-term calcium dynamics in soil and soil solution at three coniferous sites in Sweden. For Ecol Manage 302:280-294. https://doi.org/10.1016/j. foreco.2013.03.030

Zetterberg T, Köhler SJ, Löfgren S (2014) Sensitivity analyses of MAGIC modelled predictions of future impacts of whole-tree harvest on soil calcium supply and stream acid neutralizing capacity. Sci Total Environ 494-495:187-201. https://doi.org/10.1016/j. scitotenv.2014.06.114

Zetterberg T, Olsson BA, Löfgren S, Hyvönen R, Brandtberg P-O (2016) Long-term soil calcium depletion after conventional and whole-tree harvest. For Ecol Manage 369:102-115. https://doi. org/10.1016/j.foreco.2016.03.027

Publisher's Note Springer Nature remains neutral with regard to jurisdictional claims in published maps and institutional affiliations. 